\title{
A New Protection Orientation and Framework for Refugees and Other Forced Migrants
}

\author{
James C. Simeon
}

School of Public Policy and Administration, Faculty of Liberal Arts and Professional Studies, McLaughlin College, York University, 4700 Keele Street, Toronto, ON M3J 1P3, Canada; jcsimeon@yorku.ca

Received: 7 October 2017; Accepted: 6 December 2017; Published: 14 December 2017

\begin{abstract}
The unprecedented current "refugee crisis," with its 65 million plus uprooted people, demands a new protection orientation and framework for refugees and other forced migrants that are focused on the "root causes" of refugeehood, non-international protracted armed conflict or civil war. It is argued that four essential reforms are required to the international refugee protection system to respond to the "root causes" of refugees in the world today. The first calls for broadening the definition of who is a refugee to include "war refugees" as found in the 1984 Cartagena Declaration and the 1969 Organization of African Unity (OAU) Convention. The 1984 Cartagena Declaration is preferred because it has the most progressive and broadest legal definition of who is a refugee and, therefore, should be emulated by all regions and the UNHCR internationally. The second reform would be the adoption of the Cartagena Declaration decennial consultation process and its comprehensive Plan of Action by the UNHCR on a global basis. This process has proven to be a success in Latin America and ought to be adopted internationally to develop and to realize the progressive advancement of international protection for all persons who are fleeing persecution and armed conflict. The third major reform is to develop the capacity of the $\mathrm{UN}$ to be able to operate in the midst of an armed conflict situation in order to broker a ceasefire and, then, negotiate a peace agreement, particularly, in those situations where massed forced displacement has taken place or potentially could take place. The fourth reform calls for the UN to expand the Responsibility to Protect (R2P) doctrine to incorporate massed forced displacement, in addition to, war crimes, crimes against humanity, ethnic cleansing, and, genocide. This further implies that mass forced displacement ought to be criminalized and made a serious international crime, not simply in the international humanitarian law and international criminal law sense of forced deportation, transfers, and expulsions, by opposing military forces, but in situations of armed conflict when people flee of their own volition in order to save their lives. These four reforms do not require a reformulation or reconceptualization of the international refugee protection system but a reform of a number of key elements that would simultaneously address the "root causes" of refugees and, especially, mass forced displacement that is due principally to non-international protracted armed conflict or seemingly endless civil wars.
\end{abstract}

Keywords: refugees; mass forced displacement; war refugees; non-international protracted armed conflict; responsibility to protect (R2P)

\section{Introduction}

The unprecedented contemporary "refugee crisis" has reached new dimensions that can no longer be contained and requires a different orientation and framework to address. (MPI n.d.) The current momentum and consensus for addressing this humanitarian "refugee crisis" is focused on the symptoms, the mass influx situations on the shores of Southern Europe, principally, the Iberian Peninsula via Gibraltar; Lampedusa, Italy, and from Turkey through Greece, and, to a lesser extent, on the Rohingya "boat people" of Myanmar travelling to Bangladesh, Thailand, Malaysia and Indonesia 
(Declarations: The Human Rights Podcast 2017; BBC News 2015; Albert 2017). There is also a current focus on lamenting the containment and "push back" strategies of States (Frenzen 2016) and "the gap" between the collective and individual responsibilities and obligations of States under international refugee law and their failure to uphold the rights and human dignity of refugees and other forced migrants (Belgrade Centre for Human Rights et al. 2017; Human Rights Watch 2015). But, what is needed is a critical focus on the "root causes" of refugees and forced migration.

While it is absolutely essential to address the immediate suffering of those new arrivals seeking refuge from persecution and, at the same time, to decry and to lament the "push back" policies of States, "the gap" between the collective and individual responsibilities and obligations of States under international refugee law, and their failure to uphold the rights and human dignity of refugees and other forced migrants, the "root causes" of those seeking refuge must emphatically be addressed. However, even more to the point, it is absolutely vital, indeed, it is crucial, that one not forget what has brought the refugees to the desperate plight to seek the safety and security of their life and limb in another place in another country. Dealing with the immediate physical needs to sustain life through medical attention, nourishment, shelter, and companionship, all of the basic necessities of life, is far easier and immediately more gratifying than struggling for decades and with no apparent effect with the seemingly unfathomable and unsolvable "root causes" of 'refugeehood' (Refugeehood n.d.) such as systemic and deeply ingrained prejudices, social and economic inequality, bigoted oppression, religious and/or racial/ethnic discrimination and intolerance or, even closer to the mark, if at all possible, protracted armed conflict and/or war, overwhelmingly, in the form of non-internationalized armed conflict and its attendant extreme violence. Other "root causes" of forced displacement include development policies and projects and natural disasters such as drought, famine, pestilence, earthquakes, volcanic eruptions, tsunamis, hurricanes, or climate change, leading to rising sea levels with disastrous consequences to all those in its path. ${ }^{1}$

While natural disasters (earthquakes, volcanic eruptions, tidal waves, cyclones, etc.) can be immediate and have devastating effects and are often far easier to distinguish than human-made disasters (warism, racism, religionism, developmentalism, persecution, etc.), they can result in the same consequences of forcible displacement. Climate change is principally a consequence of human intervention on our planet over a long period of time and on a massive scale coupled with other natural events and activities that have dramatic effects on our environment such as global warming and its resultant consequences for our planet's ecosystem (Piguet 2008; McAdam 2012). But, ultimately, human disasters are fundamentally "political" whereas natural disasters are not (Disasterium, Natural and Man Made Disasters 2011-2015). Both have humanitarian impacts and implications that must be addressed, oftentimes in practically and essentially the same way, and, frequently, over an extended period of time. However, the fundamental point here is that even though the symptoms of mass forced displacement are the same, the "root causes" are, at their very core, different. One is "political" and the other is not.

This article calls for a new protection orientation and framework for refugees that are premised on their political "root causes" that are due to wars and armed conflict, which is overwhelmingly in the form of protracted non-international armed conflict or civil war. It commences by asserting an optimist's philosophical perspective for dealing with the "root causes" of the current "refugee crisis" by addressing the human catastrophe of war and armed conflict. It asserts that human made disasters can be confronted and alleviated contrary to the pessimist's viewpoint that wars and armed conflict are an endemic feature of humanity: a most fundamental, but, no less critical point. It considers the principal "root cause" of refugeehood, the incidence of protracted intrastate armed conflict, in some

1 Forced Migration Online (FMO) distinguishes three separate types of forced migration according to their causal factors, although they may be at times simultaneous and inter-related: conflict; development policies and projects; and, disasters. FMO also identifies seven types of forced migrants: refugees, asylum seekers, internally displaced persons, developmental displacees, environmental disaster displacees, smuggled people, and trafficked people (FMO n.d.). 
detail and outlines how it disproportionately affects women and children. In addition, it notes that more than half of the world's refugees are the consequence of three sustained and protracted armed conflicts: Syrian Arab Republic, Afghanistan, and South Sudan. It underscores the astonishing and mind-numbing statistic that more than half the world's refugees today are children. The essential point advanced is that it is imperative for the international community, as a whole, along with States and their civil societies, both individually and collectively, to deal with the "root causes" for refugees. It advances the argument that what is essential in order to address the "root causes" for refugees is to amend both international refugee law and international humanitarian and criminal law and, in conjunction, to increase the capacity of the United Nations (UN) to mediate ceasefires and peace agreements amongst opposing military forces and for the United Nations High Commissioner for Refugees (UNHCR) to undertake extensive international consultative and planning exercises on a periodic basis to address the most critical refugee protection issues and concerns.

The article calls for a new protection orientation and framework that is premised on four essential reforms to the international refugee protection system that are premised on the "root causes" of refugees in the world today. What is presented here though is not a radical reconceptualization of the international refugee protection system but, rather, a logical extension or adjustment to it given the contemporary primary causal dynamics of the production of refugees. The suggested amendments are centered not only on the protection needs of those fleeing protracted armed conflict, but, working simultaneously towards ending the very cause of those who are forcibly displaced by wars and armed conflicts.

The first reform asserts that the definition of refugee needs to be expanded to include the "war refugee." This already applies in Africa and in Latin America with the 1969 OAU Convention (UNHCR 1969; OAU Convention 1969) and the 1984 Cartagena Declaration (UNHCR 1984). Indeed, it is argued that the 1984 Cartagena Declaration definition of who is a refugee is the most progressive and expansive in existence and ought to be applied globally and not be regionally confined to Latin America alone. The second essential reform is modelled on the 1984 Cartagena Declaration decennial consultative processes that have led to a number of subsequent enhanced new Declarations and comprehensive Plans of Action that have proven to be the most systematic and progressive in advancing the plight of refugees as well as other forced migrants and, including, stateless people within Latin America and, therefore, ought to be adopted by the UNHCR on a global basis. The third essential reform calls on the United Nations to develop a greater capacity to insert itself in those armed conflict situations that have generated or can potentially generate mass forced displacement. The obvious and direct correlation between war and protracted armed conflict and forced displacement needs to be acknowledged and confronted for what it is, most fundamentally, a tactic of warfare aimed at accomplishing a military advantage, if not outright victory. Accordingly, it is argued that the Responsibility to Protect (R2P) doctrine needs to be amended to include mass forced displacement, and not just "ethnic cleansing," among its list of serious international crimes. Mass forced displacement is not only a consequence of warfare but its instrument and it ought to be criminalized for its adverse, life threating, and traumatizing effects on all civilian non-combatants.

All of these measures entail an even closer working relationship between the UNHCR and the UN, as a whole, including, other international organizations such as the International Criminal Court (ICC) (International Criminal Court n.d.a). These reforms, taken together, would have a vitally important impact on rejuvenating the international refugee protection regime and responding to the cause of peace and, hence, the "root causes" of refugees.

What augurs well in this regard is that the current Secretary-General, António Guterres, who served as the UN High Commissioner for Refugees for a decade, and who is well aware of the relationship between refugees and protracted armed conflict, is calling for measures to increase the UN's capacity for dealing with and, hopefully, resolving the key protracted armed conflicts that are generating the majority of the world's refugees. 
The article concludes by reflecting on the necessity to implement these four key essential reforms to the international refugee protection system or regime to address the principal "root cause" of refugees today and to alleviate the devastation and needless pain and suffering of so many as a consequence of seemingly "endless armed conflicts."

\section{The Optimist/Pessimist Divide in Forced Migration}

At the risk of over simplifying the essential underlying difference between those who assert that the key to addressing the plight of the world's most vulnerable persons, refugees, is to focus and to concentrate efforts on why they are being persecuted and forced to flee their homes, in the first instance, rather than focusing on other significant aspects of the refugee and forced migration cycle and/or phenomenon, I will label these two diametrically opposed approaches to refugee and forced migration concerns as the optimist's and the pessimist's viewpoints. Those who fall within the second category do not accept the feasibility or even the possibility of being able to address the "root causes" of refugeehood. While, on the other hand, some of us are persuaded to the view that human disasters can be addressed by humanity, no matter how seemingly impenetrable, inscrutable, or intractable they may seem. While others do not, concluding that extreme violence, war, destitution, and, indeed, mayhem, are inevitable features of human existence that will always be with us and, ever thus, and, therefore, ineluctably, so will the resulting refugees and other forced migrants. While this dichotomy of philosophical approaches to refugeehood may appear to be rather rudimentary and coarse, it does, nonetheless, underscore a fundamental underlying approach to dealing with "refugee crises." In fact, it may not be an exaggeration to assert that the way that we orientate ourselves to a problem determines how we perceive it and, therefore, how we are likely to address it. How we frame the problem and orientate ourselves to it, then, determines, to a great extent, how we might go about attempting to resolve it.

Those who adhere to the optimistic view of humanity believe in progress, evolution and achieving a higher good and those things that others would view impossible or beyond the realm of reality. The pessimistic view of humanity does not believe that any higher good can be achieved by humankind and that it is simply utopian to dare to do so (Domino and Conway 2001). Pessimists consider that war, famine and pestilence will never be eradicated because human nature is fundamentally flawed and it is beyond the capacity of humanity to deal with these things and, hence, we are better off not trying and saving our energies to assist those strangers who grace our shores, airports, and inland borders.

It can be argued perhaps that all progress is fused in the optimist category, while the pessimists are resigned to the status quo as being the true "reality." The pessimist will acknowledge that technological advancement is relentless, or so it seems, and humankind progresses from one method or mode of rationalization, communication, socialization, habitation, organization, transportation, production, consumption, and reproduction to another, but, human nature remains ever fixed and immutable. From this vantage point, the paramountcy of "politics" will always prevail and, thus ever, will the scrabble and struggle over scarce resource values, including, of course, the ideological. But, underlying all this is the fundamental premise that we all aspire to advance our own self-interest over and above the other's or the collective well-being. This is why pure acts of selflessness are recognized and highly praised because they are so extraordinary and exceptional in the normal course of things.

If the natural state of being human is the predominance of self-interest (Baire 1982; Egoism 2014), or more precisely "perceived self-interest," then, the paramountcy of "politics" is merely the paramountcy of "perceived self-interest." Hence, the pessimist's dilemma: how can one account for altruism - when the actions of a person have no direct or indirect benefit whatsoever to that person and may, indeed, prove to be harmful to that person? Such unnatural and deviant behavior, according to the pessimist, must prove, surely, to be the exception that proves the rule of the paramountcy of "perceived self-interest." Yet, such selfless charitable actions abound in any society when others reach out to those in need. It is natural to come to the aid of those in dire need and to ease their pain and suffering and to assist them to become self-reliant. While the pessimist is hard pressed to explain or 
to accept such altruism, the optimist accepts it as the very basis of all collaborative and cooperative behavior that advances the collective well-being of any group, community or society. Advancing the well-being of others raises the collective well-being of all within any group, community or society or, indeed, across groups, communities or societies and, hence, internationally or globally (Hilrich 2014). Thus, the natural inclination of most people is to help and to assist those in dire need or those who arrive seeking asylum from persecution.

Therefore, for the optimist, addressing the "root causes" of forced displacement and/or migration, no matter how difficult, onerous, and/or time consuming is the correct approach to finding a durable and sustainable solution to the current and future "refugee crises" confronting the world today. The challenge of refugee protection must be rooted in an understanding of the genesis and the dynamics of forced displacement and/or migration, so that these can be harnessed and addressed appropriately to end the generation of those who are forced to flee to seek refuge elsewhere and, often times, abroad; that is, outside their neighbouring countries' borders or countries of former habitual residence, if stateless. ${ }^{2}$

To summarize, then, optimists see the value of attempting to tackle the "root causes" of refugeehood, while pessimist confine themselves with dealing with the symptoms because the "root causes" are insoluble or beyond the means of humanity, given the inherent flaws of human nature. It is critical that we orient and frame the problem from the appropriate perspective of addressing the "root causes" of refugees, otherwise, the problem will never be properly dealt with and alleviated, let alone ever resolved.

\section{What Are the "Root Causes" of Refugees?}

Surely, it should be self-evident that forced displacement or forced migration is a consequence of blunt trauma that affects a person to the degree that it threatens their life, liberty or security to the point that they must flee their home and/or residence to seek refuge elsewhere. It is also important to stress that the most recent Global Burden of Disease Study (The Lancet 2017), that examines the state of the world's health by estimating average life expectancy as well as the number of deaths, illnesses, and injuries from more than 300 causes, found that since 2006, "the number of deaths from conflict and terrorism has risen significantly, reaching 150,500 deaths in 2016 (which is a 143\% increase since 2006), the researchers said. This rise is largely a result of conflicts in North Africa and the Middle East" (Rettner 2017). The trend of deaths due to armed conflict and terrorism or extreme violence is definitely on the rise.

In their seminal work, Escape from Violence: Conflict and the Refugee Crisis in the Developing World, Aristide R. Zolberg, Astri Suhkri, and Sergio Aguayo, make the following observation:

It has long been recognized that migration is governed by social and economic forces that themselves are somewhat regular and thus are amenable to theoretical analysis. By contrast, however, refugee flows are unruly in that they result from events such as civil strife, abrupt changes in regime, arbitrary governmental decisions, or international war, all of which are generally considered to be singular and unpredictable occurrences (Zolberg et al. 1989).

Zolberg et al's point here is fundamental. They argue that refugees are the consequences of violence, whether it is extreme violence in the form of international armed conflict or war, that engages two or more States, or as a result of a State's arbitrary decisions imposed on its own citizens and/or population. A brief look at the situation in the world today underscores this point. However, it also goes beyond because the most prevalent form of extreme violence is rather non-international armed conflict or intrastate war or civil war.

2 It is relevant and significant to note that the number of internally displaced persons far out numbers the number of persons who flee their countries borders to seek asylum abroad. According to the UNHCR there were 22.5 million people who were refugees at the end of 2016, but, 40.3 million internally displaced persons. (UNHCR 2017b, p. 3). 
According to the Uppsala Conflict Data Program (UCDP), at the world-renowned University of Uppsala's Department of Peace and Conflict Research, the ongoing conflict data project showed that there were 50 armed conflicts in 2015: one interstate; 29 intrastate; 20 internationalized intrastate armed conflicts (Uppsala University, Department of Peace and Conflict Research 2015). All but one of these 50 armed conflicts were not an intrastate armed conflict. Accordingly, the overwhelming predominant form of armed conflict in the world today is non-international armed conflict or intrastate armed conflict that is more commonly called "civil war." Another predominant feature of non-international armed conflicts in the world today is that they tend to be protracted and extremely difficult to resolve (Pfanner 2009). Indeed, more than half of all the States that are affected by ongoing armed conflicts are also affected by protracted armed conflicts that are persisting for more than 10 years (Marc n.d.). There are obviously multiple dimensions of conflict and violence such as land, resources and mineral extraction, horizontal and identity inequalities, regional issues, electoral competition for central power, violent ideology, trafficking in drugs and arms, migrating populations, and so on (Marc n.d.). To note that protracted armed conflict keeps countries poor is to state the obvious. But, it has been estimated that a civil war can cost a medium-sized developing country up to 30 years of GDP growth (Marc n.d.).

The fact that protracted armed conflict is the predominant driver of forced migration in the world today is evident by the latest UNHCR statistics on the world's forcibly displaced. By the end of 2016, the number of the world's forcibly displaced remained at a record high of 65.6 million people and was 300,000 more than the previous year (UNHCR 2017a). The number of persons who were forcibly displaced as a result of the overlapping factors of "persecution, conflict, violence and human rights violations" (UNHCR 2017b) has been accelerating over the last decade.

What is perhaps most telling in the forced displacement statistics is that 10.3 million were newly displaced by conflict or persecution. This included some 6.9 million people who were internally displaced within the borders of their own countries and 3.4 million new refugees and asylum seekers (UNHCR 2017b).

Astonishingly, more than half of the world's refugees (55\%) came from just three countries: the Syrian Arab Republic (5.5 million); Afghanistan (2.5 million); and South Sudan (1.4 million) (UNHCR 2017b). All of these countries have been embroiled in protracted armed conflict for years. The Syrian Civil War has been ongoing for more than six years with no end in sight. (BBC News 2016b) According to the BBC,

The conflict is now more than just a battle between those for or against Mr. Assad. It has acquired sectarian overtones, pitching the country's Sunni majority against the president's Shia Alawite sect, and drawn in regional and world powers. The rise of the jihadist group Islamic State (IS) has added a further dimension (BBC News 2016b).

The hideous nature of this civil war that has seen all forms of atrocities on all sides, such as the use of chemical weapons, barrel bombs, and the targeting of civilians makes the civil war particularly despicable (BBC News 2016b). Likewise, the Afghanistan civil war, in its current manifestation, that has been ongoing for the last 16 and more years, appears to defy any solutions. The reason why the protracted armed conflict in Afghanistan appears to be unresolvable includes:

Its combination of state collapse, civil conflict, ethnic disintegration and multisided intervention has locked it in a self-perpetuating cycle that may be simply beyond outside resolution (Fisher and Taub 2017).

The situation in South Sudan is quite dire indeed. According to Oxfam, after three years of civil war more than three million people have been forced from their homes and there are now 7.5 million people who are in need of assistance in the country (Oxfam 2017). Oxfam further points out that,

South Sudan is on the brink of catastrophe. Some 100,000 are already living in famine and nearly five million people $-40 \%$ of the population—are facing extreme hunger. More than $60 \%$ of the population -7.5 million people-are in need of humanitarian aid. 
Over three million have now been forced from their homes, with 1.3 million people having fled to neighbouring countries and approaching two million displaced within the country (Oxfam 2017).

With ongoing ethnic violence and reports of mass atrocities and the failure to make progress on the 2015 peace agreement, the prospects of achieving a durable peace in South Sudan seems highly unlikely (Guehenno 2017).

The situation in Syria, Afghanistan, and South Sudan does not appear to be improving and, consequently, the number of persons fleeing these countries will continue to grow as these protracted armed conflicts continue unabated.

UNHCR's Global Trends: Forced Displacement Report 2016 points out that $51 \%$ of the world's refugees are children (UNHCR 2017b). In comparison, only 31\% of the world's population are children. This damning statistic reveals the nature and the extent of the world's refugee crisis. A whole generation of children has been condemned to live a deprived and impoverished existence (House of Lords, European Union Committee 2016). It is not surprising then to find that the number of separated children has increased dramatically in recent years (UNICEF 2017). UNICEF has reported that there were 300,000 separated or unaccompanied children in 2015 and 2016, a five-fold increase since 2010 (UNICEF Press Release 2017). With the number of protracted armed conflicts in the world today and the record-breaking number of refugees and with half of these being below the age of 18, is it any wonder that the number of unaccompanied or separated children is increasing so dramatically? The UNHCR has reported that some 75,000 asylum applications were filed by unaccompanied or separated children. The highest number of these, 35,900, were filed in Germany. Most of these unaccompanied or separated children were either Afghans or Syrians (UNHCR 2017b).

It is also important to emphasize that $80 \%$ of the world's refugees are women and children (UNHCR 2016). Demographically, it is significant to note that more than half of the world's refugees are children but $80 \%$ are, in fact, women and children. Any reform to the current refugee protection regime must take into consideration the fundamental point that more than half the world's refugees are children (51\%) and about half were women (49\%) (UNHCR 2017b).

Tom Clark has noted that, "Clearly, if refugees correlate with violent civil conflicts and with classical forms of persecution, addressing the causes of refugees means stopping the civil conflicts and persecution" (Clark 2008). Of course, this is an enormous undertaking to say the very least. However, it is precisely what is required in order to address the "root causes" of refugeehood.

\section{The Relevance and Salience of International Human Rights Law, International Humanitarian Law and International Criminal Law to Reforming the International Refugee Protection Regime}

If the current refugee crisis is being driven primarily by protracted armed conflict, that is, the millions of people who are being forcibly displaced due to persistent and ongoing wars or armed conflicts, then, the asylum seekers may have a basis for a well-founded fear of persecution if they are being deliberately targeted, by one or the other side of those who are engaged in the conflict, due to their race, ethnicity, religion, political opinion or membership in a particular social group. Convention refugee status under the 1951 Convention relating to the Status of Refugees (1951 Convention) requires that the refugee claimant to establish that they have a basis to a well-founded fear of persecution on one of the five grounds of the 1951 Convention, as noted above. Accordingly, not everyone who flees a war zone is necessarily a refugee under the 1951 Convention and its 1967 Protocol.

The UNHCR's 2011 Handbook on Procedures and Criteria for Determining Refugee Status, addresses this issue at paragraphs 164 to 166 (UNHCR 2011). It notes that those who flee international or national armed conflicts are not normally considered refugees under the 1951 Convention and 1967 Protocol. There are other international instruments that are intended to protect civilians who are in a war setting such as the 1949 Geneva Conventions on the Protection of War Victims and the 1977 Protocol additional to the 1949 Geneva Conventions related to the Victims of International Armed Conflicts.

The UNHCR further notes in paragraph 165 that, 
... refugee status will depend upon whether the applicant is able to show that he has a "well-founded fear of being persecuted" in the occupied territory and, in addition, upon whether or not he is able to avail himself of the protection of his government, or of a protecting power whose duty it is to safeguard the interests of his country during the armed conflict, and whether such protection can be considered to be effective (UNHCR 2011).

The essential point here is that anyone fleeing a war zone is not necessarily a Convention refugee unless they can demonstrate that they have a well-founded fear of persecution on one of the five grounds of the 1951 Convention and they cannot avail themselves of effective State protection. ${ }^{3}$

Committing crimes during times of war, like times of peace, can result in charges, arrest, prosecution, trial, conviction, and sentencing. This can apply nationally and internationally as well with the establishment of the International Criminal Court (ICC) with the adoption of the Rome Statute 17 July 1998 that came into force 1 July 2002, for the most serious international crimes such as genocide, crimes against humanity, war crimes, and aggression. ${ }^{4}$ The establishment of the ICC was a major step toward better implementation of International Humanitarian Law (IHL) as well as the battle to end impunity. (ICRC Customary IHL n.d.) However, the practical challenge of utilizing IHL for the protection of those who find themselves in an armed conflict situation is that IHL is really post hoc in and of itself. The breach in IHL takes place and, then, the incident has to be brought to the attention of the authorities involved, investigations have to be undertaken, the evidence gathered must be weighed and assessed, and a decision whether to lay charges and to pursue a prosecution must be made. The breach in IHL may occur in the midst of an armed conflict and it could take months, if not years, before the matter comes to light and an investigation can be undertaken. The practical utility of IHL for civilian non-combatants is meaningless under the conditions of extreme violence. IHL may be of assistance and relevance under conditions of belligerent occupation. ${ }^{5}$

Emanuela-Chiara Gillard has outlined the relationship between international humanitarian law and international refugee law as follows:

Recognising that the majority of persons forced to leave their state of nationality today are fleeing the indiscriminate effect of hostilities and the accompanying disorder, including the destruction of homes, foodstocks and means of subsistence-all violations of international humanitarian law—but with no specific element of persecution, subsequent regional refugee instruments, such as the 1969 OAU Refugee Convention and the 1984 Cartagena Declaration on Refugees have expanded their definitions to include persons fleeing armed conflict (Gillard 2005).

3 (Immigration and Refugee Board of Canada 1996) The first General Proposition outlined in these Guidelines is, "There is nothing in the definition of Convention refugee which excludes its application to claimants fearing return to situations of civil war. Conversely, those fearing return to situations of civil war ought not to be deemed Convention refugees by that fact alone." Quoting the Federal Court of Appeal (FCA) judgement in Salibian v. M.E.I., [1990] 3 F.C. 250 (C.A.), the Guidelines outline the four principles outlined by the FCA, including: "a situation of civil war in a given country is not an obstacle to a claim provided the fear felt is not that felt indiscriminately by all citizens as a consequence of the civil war, but that felt by the applicant himself, by a group with which he is associated, or, even, by all citizens on account of a risk of persecution based on one of the reasons stated in the definition."

4 "The ICC is not intended to take over jurisdiction exercised by national courts: the ICC is intended to exercise its jurisdiction only when the state is unwilling or genuinely unable to prosecute. States continue to have the primary duty to prosecute suspected war criminals before their own courts." (ICRC 1998). National courts can also exercise universal jurisdiction to prosecute individuals for any serious crimes against international law such as war crimes, crimes against humanity, genocide, and torture. This is based on the principle that such serious international crimes harm the international community which individual States may act to protect. See (International Justice Resource Center n.d.; Global Policy Forum n.d.).

5 "The law of belligerent occupation (which from now on we will refer to simply as the law of occupation) governs the relationship between the occupying power, on the one hand, and the wholly or partially occupied State and its inhabitants, including refugees and stateless persons, on the other. It is applicable only in international armed conflicts." (ICRC 2002, p. 2). There is, of course, a deterrent effect of IHL that cannot be denied. But, as everyone knows not all crime is deterred by criminal law. In fact, some criminal laws can have the opposite effect in promoting organized criminal activities. The classic example is the prohibition of the sale of alcohol in the United States from 1920 to 1933 (Prohibition, United States History 1920-1933). 
Gillard, then, goes on to point out that,

Moreover, states that are not party to these regional instruments (1969 OAU Convention and 1984 Cartagena Declaration) have developed a variety of legislative and administrative measures, such as the notion of "temporary protection" for example, to extend protection to persons fleeing armed conflict (Gillard 2005).

Gillard further notes that there is a second interface between international humanitarian law and international refugee law that deals with the issues of exclusion of claimants from Convention refugee status. "Violations of certain provisions of international humanitarian law are war crimes and their commission may exclude a particular individual from entitlement to protection as a refugee" (Gillard 2005).

The main point here is that there is regional variation in the definition of who is a refugee that is dependent on where a refugee seeks to make their claim for refugee protection. In Africa and in Latin America the definition of who is a refugee encompasses those who are fleeing armed conflict and in other regions such as Europe and in North America the definition of who is a refugee does not encompass those who are fleeing armed conflict (Storey 2012). Temporary protection measures are not equivalent to Convention refugee status. These regional "gaps" in refugee protection need to be addressed.

The most progressive and advanced definition of who is a refugee is the one that is found in the 1984 Cartagena Declaration that builds on the 1969 OAU Convention of who is a refugee. Rather than the "patch work quilt" of variations in the definition of who is a refugee, that is dependent on regional Conventions, there should be one universal standard for who is a refugee across all regions. Given the relationship between war, armed conflict, and forced displacement and the ever seemingly increasing numbers of refugees in the world today, that are overwhelmingly children and women, it only stands to reason that this would be the most sensible and most reasonable thing to do to advance the protection of all those who are fleeing from extreme violence in the form of intrastate armed conflict, the most virulent and atrocious form of warfare.

All States should adopt the definition of who is a refugee that is found in the 1984 Cartagena Declaration that states, at Article III (3), as follows:

TO REITERATE that, in view of the experience gained from the massive flows of refugees in the Central American area, it is necessary to consider enlarging the concept of a refugee, bearing in mind, as far as appropriate and in the light of the situation prevailing in the region, the precedent of the OAU Convention (article 1, para. 2) and the doctrine employed in the reports of the Inter-American Commission on Human Rights. Hence the definition or concept of a refugee to be recommended for use in the region is one which, in addition to containing the elements of the 1951 Convention and the 1967 Protocol, includes among refugee persons who have fled their country because their lives, safety or freedom have been threatened by generalized violence, foreign aggression, internal conflicts, massive violation of human rights or other circumstances which have seriously disturbed public order (UNHCR 1984, Emphasis added).

It is also important and relevant to note that the 'Cartagena Declaration process' has continued over the years and that on December 2014 at a Ministerial Meeting in Brazilia, the UNHCR and the representatives of 28 States and three territories in Latin America and the Caribbean adopted the Brazil Declaration and Plan of Action, that came at the end of the 30th anniversary commemorative process known as Cartagena +30 . (UNHCR 2014) The UNHCR has described the process in the following terms:

Participants adopted by acclamation the Brazil Declaration and Plan of Action, agreeing to work together to uphold the highest international and regional protection standards, implement innovative solutions for refugees and other displaced people and end the plight of stateless persons throughout the region within a decade. 
The Brazil Declaration builds upon previous regional frameworks, including the 1994 San José Declaration on Refugees and Displaced Persons, which focused on internal displacement, and the 2004 Mexico Declaration and Plan of Action to Strengthen the International Protection of Refugees in Latin America (UNHCR 2014).

What is interesting and unique about the Brazil Declaration is that it is so thorough and comprehensive and it includes a detailed Plan of Action. It certainly marks the high point in not only building on an international instrument but also developing a program for achieving its progressive realization. In this regard, it stands as a model that all other regions ought to be emulating. It sets specific goals and targets and provides a road map for how States can achieve these within a reasonable period of time.

The critical point here is that the broadest definition of who is a refugee is found in the Cartagena Declaration, with its comprehensive and detailed Plan of Action that sets out a strategy for how to advance the protection of not only refugees but internally displaced persons as well as stateless persons. Furthermore, each decade it has undertaken a commemorative consultation process that has led to broadening the number of vulnerable persons of concern that it has sought to protect as well as incorporated a specific Plan of Action for how the States in the region could achieve these goals and targets. Moreover, and most importantly, it encompasses all those who have been displaced by armed conflict which is currently, the world's principal cause of refugees.

It should not only be emulated by all of the other regional refugee systems, but, internationally as well. The UNHCR should be using the Latin American and Caribbean regional model for refugee protection and other persons of concern for achieving key goals over the course of a decade. But, critical to this is a workable guide or road map for how States can achieve these goals through a comprehensive "Plan of Action." At present, there are no such arrangements that are led by the UNHCR. There are the annual Executive Committee meetings, with the Note on International Protection (UNHCR 2017a), and the consultations with NGOs and the annual protection reports to the United Nations General Assembly (United Nations 2016; UNHCR, Conferences and Meetings n.d.). But, what is required is a clear Plan of Action, like the Cartagena Declaration decennial process with its comprehensive and detailed Plan of Action.

The UNHCR's Agenda for Protection, Convention Plus, and the High Commissioners Forum Meetings were somewhat similar to the Cartagena Declaration's decennial consultation process and Plans of Action. (Clark and Simeon 2014) Past assessments of the UNHCR's Agenda for Protection (UNHCR 2003) have been positive in helping to shape the refugee protection agenda for States and the international community (Clark and Simeon 2014). However, this is not the same as the Cartagena Declaration decennial consultation process and Plans of Action. In addition, this is precisely what the UNHCR and the international community ought to be considering in reforming the international refugee protection regime (Chimni 2001, p. 151). ${ }^{6}$ It should be a process of gradual evolution and development through sustained ongoing consultations and general agreement on the goals, to be set over a fixed period, with a workable and specific Plan of Action to realize these goals. Through such a process, along with an implementation plan, the international refugee protection regime can be progressively reformed with the support of State Parties to the principal international refugee rights instruments to meet the growing protection needs of refugees and other persons of concern to the UNHCR.

Broadening the definition of "who is a refugee" to include all those whose "lives, safety or freedom have been threatened by generalized violence, foreign aggression, internal conflicts, massive violation of human rights or other circumstances which have seriously disturbed public order," (UNHCR 1984), to the most progressive definition of who is a refugee, may not be as challenging as it might seem. It is vitally

6 This global consultation process leading to a specific plan of action is somewhat similar to the spirit of B. S. Chimni's well-known article "Reforming the International Refugee Regime: A Dialogic Model" (Chimni 2001). For instance, it should be premised on the principles of "deliberative democracy which allow good arguments to prevail." 
important to note that the Cartagena Declaration is a non-binding regional instrument that allows States within the region to adopt its provisions into national law. Using this as a model, the United Nations General Assembly, with the support of the Latin American States that have acceded to the Cartagena Declaration, could adopt a similar non-binding declaration that States could then adopt into national law on a voluntary basis. Hopefully, overtime and with the encouragement of the UN and its agencies, States would be encouraged to incorporate this boarder definition in their national laws.

Implementation of the Cartagena Declaration decennial consultation process and Plan of Action at the international level would require the leadership of the UNHCR, the UN, and Latin American States that are already engaged in this process, would encourage the international community to adopt this decennial consultation process that would produce a comprehensive Plan of Action for all UN Member States. This would require the UNHCR's Executive Committee's approval, and that of the UN General Assembly, along with the support of the Latin American States that are already implementing this process at the regional level. The non-binding nature of such an exercise would allow for the broad-based support for such an initiative and would likely be welcomed by most States as setting clear expectations and a "road map" for how to meet the challenges in providing refugee protection over the course of a decade.

\section{Addressing the "Root Causes" of Refugees by Concentrating on Ending Wars and Protracted Armed Conflicts}

It is patently evident that in order to stop the ever-growing numbers of refugees, the international community will need more seriously to address how to end wars and protracted armed conflicts, which are the principal cause of refugees in the world today. Ending wars and armed conflicts are highly sensitive and complex political and diplomatic undertakings and clearly are very far from simple and straightforward exercises (Woolf 2016). The United Nations is, of course, the international organization that has been tasked, collectively by its member States, with the responsibility of preventing and resolving wars and armed conflicts. It has had mixed results, at best, in doing so (United Nations Peacekeeping n.d.; Spencer 2015). However, the United Nations is not alone in working toward the peaceful settlement of disputes within and among States. Regional organizations such as the European Union, African Union, and Organization of American States have a duty to maintain the peace within and among their member States. Other regional partners in maintaining international peace and security include the Association of South East Asian Nations (ASEAN), the Collective Security Organization (CSTO), the Arab League or League of Arab States (LAS), the North Atlantic Treaty Organization (NATO), and the Organization for Security and Cooperation in Europe (OSCE) (United Nations 2015). And, States, individually, have a responsibility to maintain the peace within their borders and with other States.

Peacekeeping is one of the most important operational duties of the United Nations. ${ }^{7}$ It is important to keep in mind the extent and the nature of UN's Peacekeeping operations. Globally, there are 15 Peacekeeping operations, tasked with a variety of duties that involve about 122,000 troops, police and civilian personnel from 124 countries, with a budget of 8.27 billion US dollars (United Nations Peacekeeping n.d.), It is noteworthy that the United Nations does not have Peacekeeping Missions in two of the three highest refugee producing countries: Syria, Afghanistan, and South Sudan

7 “UN Peacekeeping is guided by three basic principles:

- Consent of the parties;

- Impartiality;

- Non-use of force except in self-defence and defence of the mandate.

Peacekeeping is flexible and over the past two decades has been deployed in many configurations. There are currently 15 UN peacekeeping operations deployed on four continents." United Nations Peacekeeping, "What is peacekeeping?" http:/ / www.un.org/en/peacekeeping/operations/peacekeeping.shtml (accessed on 29 September 2017). 
and, as previously noted, account for 55\% of the world's refugees (UNHCR 2017b). Its Peacekeeping Mission in South Sudan, United Nations Mission in South Sudan (UNMISS), consists of the following: 11,782 troops; 1105 police, 1973 civilians that are intended to protect civilians and to monitor human rights. ${ }^{8}$ Although the UN does not have a Peacekeeping Mission in Afghanistan, it does have a United Nations Assistance Mission in Afghanistan (UNAMA) (UNAMA n.d.). UNAMA was established by UN Security Council Resolution 1401 in March 2002 at the request of the Islamic Republic of Afghanistan and it is reviewed annually (United Nations, Department of Political Affaris, UNAMA, Mandate n.d.). According to the UNAMA website, its mandate is as follows:

UNAMA is a political mission that provides political good offices in Afghanistan; works with and supports the government; supports the process of peace and reconciliation; monitors and promotes human rights and the protection of civilians in armed conflict; promotes good governance; and encourages regional cooperation (United Nations, Department of Political Affaris, UNAMA, Mandate n.d.).

In fact, UNAMA has field offices across Afghanistan and employs more than 1500 staff that consists of 1150 Afghan nationals, 350 international staff and 75 UN volunteers (United Nations, Department of Political Affaris, UNAMA, Mandate n.d.).

What is surprising is that the United Nations has not recently undertaken any Peacekeeping Missions for Afghanistan or Syria. ${ }^{9}$ Given the intensity of the armed conflicts continuing in both States, this may preclude the possibility of such missions. The three basic principles of United Nations Peacekeeping, as noted, are: consent of the parties; impartiality; and, the non-use of force except in self-defense and defense of the mandate (United Nations, Department of Peacekeeping Operations, Department of Field Support 2008). The first principle in UN Peacekeeping is likely not to be met in Syria. Nonetheless, the absence of full UN Peacekeeping Mission in Syria and Afghanistan, in the world's two highest refugee producing countries, is highly noticeable. However, this does not mean that the UN is not active in trying to further peace negotiations in Syria or Afghanistan. The UN has a Special Envoy for Syria, Mr. Steffan de Mistura, who is working to broker a peace agreement amongst all the parties (UN News Centre 2017; Hilal 2015). Tadamichi Yamamoto is the Special Representative and the head of the United Nations Assistance Mission in Afghanistan (UNAMA) and he has called for all parties to enter the peace process and to reject "endless war." (UN News Centre 2016a) A two-day meeting was held in Brussels, Belgium, on 4-5 October 2016, hosted by the European Union and the Government of Afghanistan that included 70 countries and 20 international organizations "to provide an opportunity to signal sustained political and financial support to Afghanistan's peace, state-building, and development" (UN News Centre 2016b). The efforts to build a durable and lasting peace in Afghanistan are certainly underway. Nonetheless, the situation in Afghanistan still remains volatile (Boot 2017).

What this suggests, however, is that irrespective of United Nations' current preventative diplomacy and mediation efforts through its Department of Political Affairs, that in certain specific circumstances, the United Nations needs to continue to establish and to develop its capacity to work within an armed conflict situation to help to build the peace, even in the midst of an armed conflict. ${ }^{10}$

8 “The 2013 crisis reprioritized UNMISS's mandate towards the protection of civilians, human rights monitoring, support for the delivery of humanitarian assistance and support to the IGAD [Intergovernmental Authority on Development is a regional development organization in East Africa] peace process." United Nations, Peacekeeping brochure, un.org/peacekeeping, http:/ / www.un.org/en/peacekeeping/documents/UN_peacekeeping_brochure.pdf (accessed on 29 September 2017).

9 There was a Peacekeeping Mission in Afghanistan and Pakistan from May 1988 to March 1990, the United Nations Good Offices Mission in Afghanistan and Pakistan (UNGOMAP). See United Nations Peacekeeping, Past Peacekeeping Operations, http:/ / www.un.org/en/peacekeeping/operations/past.shtml (accessed on 1 October 2017). There was also a brief United Nations Supervision Mission in Syria (UNSMIS) that operated from 12 April 2012 to 19 August 2012, to monitor the cessation of armed violence. See UNSMIS, United Nations Supervision Mission in Syria, http:/ / www.un.org/en/peacekeeping/ missions/past/unsmis/ (accessed on 1 October 2017).

10 It is relevant to point out that the United Nations Department of Political Affairs (DPA) is tasked with the responsibility for preventing and resolving "deadly conflict around the world." (See United Nations, Department of Political Affairs, 
(Crocker 2017) This would appear to be beyond the current Peacekeeping Operations of the UN or the appointment of Special Representatives or Envoys as in the situation of UNAMA in Afghanistan. What appears to be required is an operation that, not unlike the International Committee of the Red Cross (ICRC), would be working behind the scenes to broker a cessation of hostilities and, then, a peace agreement while, at the same time, advancing the protection of civilians in order to limit the perilous dynamics of mass forced displacement.

It has been argued that mass forced displacement is a deliberate war strategy on the part of opposing combatants to advance their tactical and strategic position in an effort to achieve victory.

With the steady rise in the average number of internally displaced persons (IDPs) per conflict in recent years, the data suggests that forced displacement has become a deliberate and widespread tactic (Von Einsiedel et al. 2017).

Adam Lichtenheld has noted that, "Population displacement has long been employed as a tool of statecraft and a weapon of war" (Lichtenheld 2014). He goes on to point out that,

Relocating communities enables authorities to assert control over contested areas, monitor restive populations, drain rebel-held territories of recruits and resources, and limit collateral damage. While those responsible commonly justify these strategies under the auspices of protecting civilians, they rarely provide the resources needed to address the humanitarian consequences (Lichtenheld 2014).

Lichtenheld concludes by asserting that, "If there are any types of forced migrations that we should be able to deter or prevent, it is those that are deliberately planned and executed by states and other armed actors" (Lichtenheld 2014). However, this is far easier said than done as starkly evident from the use of this tactic in the present Syrian civil war.

After five years of conflict, many observers believe the Syrian regime has finally begun to reap the benefits of its siege of cities and neighborhoods outside of its control. It has rid them of opposition, changed their sectarian makeup, and brought in other groups that conform with the regime's policies and desires. This happened recently in Darayya and is currently occurring in Muadamiyat al-Sham, outside of Damascus, and the neighborhood of al-Waer in the city of Homs. Many fear that Assad's strategy of forced displacement and demographic change will also be directed towards the city of Aleppo in northern Syria-home to nearly two million people before the war began. Now, less than 300,000 people remain in the besieged city, where they suffer from starvation and daily bombings (Al-Jablawi 2016).

Indeed, forced displacement has even been described as a "weapon of mass migration" (Greenhill 2010b). Kelly Greenhill, for instance, has defined "coercion engineered migrations (or coercion-driven migrations)" in the following terms: "those cross-border population movements that are deliberately created or manipulated in order to induce political, military and/or economic concessions from a target state or states" (Greenhill 2010a). As Federico Andreu-Guzman has argued, in the context of Colombia,

The crime of forced internal displacement is not a new phenomenon in Colombia. It has been a widespread practice in the country's internal armed conflict for several decades.

http:/ / www.un.org/undpa/en/overview (accessed on 22 November 2017)). Its website notes that, “DPA acts as a center for expertise on preventive diplomacy, mediation and peacemaking, whose services are available to UN and non-UN envoys alike." In this regard, it has a Meditation Support Unit (MSU) that was established in 2006 that works closely with DPA's regional divisions to plan and support mediation efforts in the field. See (United Nations Department of Political Affairs n.d.). In this regard, DPA has an online mediation support tool, UN Peacemaker, which is intended for peacemaking professional that includes "an extensive database of peace agreements, guidance material and information on the UN's mediation support services." See (United Nations Peacemaker n.d.). 
However, forced internal displacement cannot be reduced to an inherent or unintended effect of the conflict. The armed actors in the Colombian armed conflict-the army and its paramilitary groups, on one hand, and the guerrilla groups, on the other-have used the practice of forced displacement of civilian populations as part of their military strategies to take control of or maintain a presence in certain territories. The practice involves expelling people considered to be an actual or potential part of the social base of the enemy, in order to ensure control of territories and populations. Several of the Colombian army's manuals on counterinsurgency operations classify the "internal enemy" or "subversive forces" as "armed groups" and "insurgent civilian populations" (Andreu-Guzman 2012).

All of this underscores the necessity of the United Nations to play a much more profound role to ensure that mass forced displacement is not being used as a tactic of warfare. The mass influx of refugees into neighbouring countries and countries further abroad creates internal as well as external political pressures on host States and their societies. This further demonstrates the old adage that wars affect everyone and not just the direct combatants. It also highlights Secretary-General Guterres' statement to the UN Security Council on the protection of civilians in armed conflict,

No one is winning today's wars; everybody is losing. I appeal to all leaders, parties to conflict and those with influence to bring these raging conflicts to an end, and to do all in their power to prevent new ones from erupting (United Nations 2017b).

There is a Responsibility to Protect (R2P) civilians during these types of special situations. It goes without saying, of course, that States have a responsibility to protect their populations from genocide, war crimes, ethnic cleansing, and crimes against humanity (United Nations 2009). If any State fails to protect its citizens from these gross international crimes, then, with the authorization of the UN Security Council for intervening in a State to protect its population would be fully warranted. Although aggression is not included in this list of serious international crimes that are covered by the Rome Statute, aggression now falls within the prosecutorial responsibility of the International Criminal Court. It is evident that all of these serious international crimes occur, generally, within the circumstances or situation of war or an armed conflict. These are also, obviously, and generally, the triggers for forced displacement, whether coercively engineered or spontaneous.

It is important to underscore that the 1949 Fourth Geneva Convention relative to the Protection of Civilian Persons in Time of War, Article 49, states,

Individual or mass forcible transfers, as well as deportations of protected persons from occupied territory to the territory of the Occupying Power or to that of any other country, occupied or not, are prohibited, regardless of their motive.

It goes on to state,

The Occupying Power shall not detain protected persons in an area particularly exposed to the dangers of war unless the security of the population or imperative military reasons so demand.

The Occupying Power shall not deport or transfer parts of its own civilian population into the territory it occupies.

Customary International Humanitarian Law, according to the International Committee of the Red Cross (ICRC), notes under Chapter 38, Displacement and Displaced Persons, Rules 129 to 133, and states at Rule 129, The Act of Displacement, that, 
A. Parties to an international armed conflict may not deport or forcibly transfer the civilian population of an occupied territory, in whole or in part, unless the security of the civilians involved or imperative military reasons so demand.

B. Parties to a non-international armed conflict may not order the displacement of the civilian population, in whole or in part, for reasons related to the conflict, unless the security of the civilians involved or imperative military reasons so demand (ICRC Customary IHL n.d.).

It is important to note that the displacement of people, in the form of deportation, transfers or expulsions by military forces, can be a crime under international humanitarian law as well as international criminal law (ICRC Customary IHL n.d.). This is a well-established principle under both of these branches of international law. Consequently, there is already a prohibition on forced displacement by opposing military forces in either an international or non-international armed conflict. It has been argued that,

Acts of forced displacement, whether in international armed conflict, in civil wars, or even in peace time (if the other requirements for crimes against humanity are met) amount to international crimes. Even the difference established by the ICTY between deportation and forcible transfer-should it be accepted by other tribunals in the future-does not change the basic point that all of these acts are criminal, and that forcibly transferring people within a country is as serious as deporting them across a State border (Acquaviva 2011).

Hence, there is a "crime of forced displacement" in international law, but, for it to be "a crime at all it has to be 'arbitrary displacement' that has been ordered or committed without any grounds on international law" (Andreu-Guzman 2013). However, people flee war zones to avoid the obvious threats of life and limb due to aerial bombardment, cross-fire, collateral damage, spread of disease, lack of water, food and medical supplies, and so on, despite the general principles and the provisions of international humanitarian law and international criminal law that at least in theory, but, clearly not always in practice, that are intended to protect them from these types of harm (Joseph 2017). This is where there is a further role for the United Nations: to address the needs of those who must flee a war zone because the conditions there are simply unbearable in spite of the assumed protection of international law.

The R2P doctrine needs to be applied in those situations where there is mass forced displacement and whether or not it is taking place in armed conflict situations and circumstances (Bellamy 2016). A further principle needs to be developed, adopted, and applied whenever there is mass forced displacement. There is an obligation on the part of the UN and, more specifically, its Security Council, despite the veto powers of its five permanent members, to intervene to broker a cease fire and to end the armed conflict, as quickly as possible, in order to protect the State's population. This could be facilitated by an expansion of the R2P doctrine to include mass forced displacement that is seemingly now recognized as a tactic of armed conflict. In essence, then, the use of mass forced displacement as an instrument of war, irrespective of whether it is arbitrary or non-arbitrary or coercively engineered or spontaneous, should be recognized as a serious international crime.

In this regard, it should be noted that "ethnic cleansing" has been described by the International Committee for the Red Cross (ICRC) in the following way,

"Ethnic cleansing" aims to change the demographic composition of a territory. In addition to displacement of the civilian population of a territory, this can be achieved through other acts which are prohibited in and of themselves such as attacks against civilians (see Rule 1), murder (see Rule 89) and rape and other forms of sexual violence (see Rule 93). These acts are prohibited regardless of the nature of the conflict and have been widely condemned (ICRC Customary IHL n.d.). 
All of this is to say that by strengthening the R2P doctrine not only to include the notion of "ethnic cleansing," 11 but to include non-arbitrary or spontaneous forced displacement, in its broadest sense, and not simply in terms of either international humanitarian law and/or international criminal law, would help to address the perilous situation of those who have to flee a war zone in order to protect their life and limb by virtue of the situation and circumstances of continuous armed combat.

Criminalizing mass forced displacement within the context of armed conflict, beyond what is already recognized currently as a 'crime of forced displacement' in International Humanitarian Law and International Criminal Law, as outlined above, should begin with the expansion of R2P to include mass forced displacement for what it is, an atrocity crime, along with "ethnic cleansing." This can be done in a similar manner to that of the R2P doctrine when it was first adopted by UN Member States at the 2005 UN World Summit and, subsequently, by UN General Assembly resolutions (United Nations Office of Genocide Prevention and Responsibility to Protect n.d.).

The Rome Statute of the International Criminal Court can then be amended, accordingly, under Article 121 and 122 of the Statute. (Rome Statute of the International Criminal Court 1998) Presumably, the incorporation of 'mass forced displacement,' outside of the already criminalized deportation, forcible transfers, and expulsion, as an amendment to the Rome Statute would follow the same procedures as the amendment that led to the incorporation the crime of aggression within the mandate of the International Criminal Court (International Criminal Court n.d.b). These processes, obviously, take a great deal of effort and time to realize. However, the positive examples of the adoption of R2P doctrine by the United Nations and the establishment of the International Criminal Court, and the subsequent amendment of the 1998 Rome Statute to include the crime of aggression, demonstrates the feasibility, practicality and necessity of such reforms (Islam 2016).

The UN Secretary-General's Report on "United Nations Activities in Support of Mediation," describes the extent of the challenge that it faces in the following terms:

The number of major civil wars almost tripled in the decade to 2015. Between 2011 and 2015, there was a six-fold increase in the number of fatalities in conflict, with 2014 being second only to 1994, the year of the Rwandan genocide, as the deadliest year since the cold war. The total number of casualties remains historically high, although 2016 did see declines in the numbers of both armed conflicts and fatalities. Displacement attributable to armed conflict is at the highest level on record, involving more than 65 million people. Moreover, at least 20 million people are facing famine in (northern) Nigeria, Somalia, South Sudan, and Yemen, all countries with protracted armed conflicts and access constraints (United Nations 2017a).

The role of mediation at the United Nations is a major one that is intended to assist in the Herculean task of "enabling more effective conflict prevention and peacemaking" (United Nations 2017a). The United Nations is placing a greater priority and is investing more resources in an effort to increase its capability to mediate conflict situations and to carry out peacemaking.

The fact that António Guterres is the Secretary-General of the United Nations augurs well with respect to addressing the "root causes" of refugees through mediation and an increased emphasis and focus on peacemaking at the United Nations (UN News Centre 2016b). Guterres served as the UN High Commissioner for Refugees from June 2005 to December 2015, more than a decade, and he is

11 "As ethnic cleansing has not been recognized as an independent crime under international law, there is no precise definition of this concept or the exact acts to be qualified as ethnic cleansing. A United Nations Commission of Experts mandated to look into violations of international humanitarian law committed in the territory of the former Yugoslavia defined ethnic cleansing in its interim report S/25274 as ' . . rendering an area ethnically homogeneous by using force or intimidation to remove persons of given groups from the area." In its final report S/1994/674, the same Commission described ethnic cleansing as "... a purposeful policy designed by one ethnic or religious group to remove by violent and terror-inspiring means the civilian population of another ethnic or religious group from certain geographic areas.'" (United Nations Office of Genocide Prevention and Responsibility to Protect n.d.). 
all too familiar with the plight of refugees and other persons of concern. His ten years' experience working on the frontline of the perils of refugeehood and trying to address the needs of refugees provides him with the necessary understanding and insight to be able to connect the suffering of refugees to protracted armed conflict and warfare. Indeed, this may be why Guterres was unanimously selected as the UN Secretary-General among a number of highly qualified candidates (Chrisafis and Borger 2017; BBC News 2016a).

However, what the United Nations should be doing is playing more of a role in those nations that are embroiled in armed conflict to end the fighting and initiate peace agreements and this should be the prime focus of the UN to address those States that have been embroiled in armed conflict the longest, in an effort to end the fighting and to win the peace. This would do more to end forced displacement than anything else.

In this regard, UN Secretary-General, in a recent interview, stated that,

The UN must, first of all, be an instrument for a surge in diplomacy for peace and we are doing everything we can, facing all the crises that we have-from Mali to South Sudan to Libya to Central African Republic to Syria to Afghanistan to Somalia-to do everything we can to convince the parties to those conflicts and those that have leverage, that support the parties to the conflict, we are doing everything we can to convince them that these are wars that nobody is winning; everybody's losing (UN News Centre 2017).

Certainly, "a surge in diplomacy for peace" is what is necessary to end the seemingly endless armed conflicts that are besieging the world today and also to end the wars in the three largest refugee producing countries in the world today.

\section{Conclusions}

There is no question that a new protection orientation and framework is required to try and to deal with the seemingly growing and never ending "refugee crises" in the world today. Mass forced displacement is directly and intimately linked to the intrastate protracted armed conflicts or civil wars that are raging in Africa, the Middle East, and Latin America as well as other parts of the world. It is imperative, therefore, to address the "root causes" of forced displacement and not merely its symptoms. Although, obviously, it is crucial that we also tend to the welfare of those who are seeking refuge from the scourge of seemingly endless armed conflicts. However, without addressing seriously the "root causes" of refugeehood, the attendant political, social, and economic impact of sustained mass forced displacement, for both those seeking refuge and those providing asylum will escalate.

While pessimists are resigned to the view that wars and armed conflict are inevitable and, consequently, so are refugees and other forced migrants, optimists are more inclined to accept that wars and armed conflict can be contained and limited, if not entirely eliminated. Clearly, optimists are prepared to try to address the "root causes" of refugees, while pessimists are not. Fortunately, the United Nations is premised on the notion that armed conflict, war and other forms of extreme violence can be contained, reduced and, ultimately, eradicated. ${ }^{12}$

12 The Preamble of the United Nations Charter states the following objectives:

- to save succeeding generations from the scourge of war, which twice in our lifetime has brought untold sorrow to mankind, and

- to reaffirm faith in fundamental human rights, in the dignity and worth of the human person, in the equal rights of men and women and of nations large and small, and

- to establish conditions under which justice and respect for the obligations arising from treaties and other sources of international law can be maintained, and

- to promote social progress and better standards of life in larger freedom,

See (United Nations n.d.). 
It is evident from what is noted above that there has to be a greater effort on the part of the United Nations and its member States to make the linkage between protracted armed conflict and forced displacement and the mass production of refugees. In this regard, the definition of who is a refugee should include, as it already does in Africa and many countries in Latin America, the broader definition of refugee that includes those who flee war or armed conflict. Indeed, the 1984 Cartagena Declaration decennial consultation process that has resulted in a broadening of those it is providing protection, in addition to refugees, within its region, includes a comprehensive Plan of Action, that ought to be emulated by all regions and also adopted by the UNHCR, both in terms of its scope but its comprehensiveness that includes a detailed road map of how to implement its Plan of Action on a global basis.

Addressing the "root causes" of refugees, of course, means that you must end persecution, wars and protracted armed conflicts. The UN needs to develop a greater capacity to operate within the midst of non-international armed conflicts in order to broker a cease fire and to try to negotiate peace agreements and settlements. This is not only consistent with the UN's R2P doctrine but it points to the necessity of developing, adopting, and implementing a new principle for the UN's intervention in any armed conflict or non-armed conflict situations that have resulted in or potentially could result in mass forced displacement. This should be applied immediately in the three largest refugee producing countries in the world today that account for a shocking $55 \%$ of the world's refugees.

With António Guterres now as the new UN Secretary-General, calling for a "surge in diplomacy for peace," strengthening the UN's professional mediation capacity, and calling on States to undertake progressive measures to deal with political, social, and economic inequalities, all augurs well for the UN and its agencies' efforts in trying to address the "root causes" of refugees.

The reforms presented here are far from radical and at least for the first two, an expansion of the international definition of refugee to include "war refugees" and the adoption of the Cartagena Declaration decennial consultation process leading to a comprehensive Plan of Action, are both tried and true measures that are already applied in Latin America and to a great extent, at least for the more expansive definition of refugee, in Africa. The last two reforms, that involve developing the UN's capacity to insert itself in the midst of war or armed conflict situations to try to negotiate a ceasefire and eventually help to negotiate a peace agreement along with the criminalizing of mass forced displacement in a protracted armed conflict situation as a serious international crime, and incorporating it with R2P doctrine, is perhaps far more controversial and challenging. Nevertheless, these complementary reforms could do much to help to reach peace agreements and, at the same time, seek to eliminate the deliberate use of mass forced displacement as a weapon of war. Together these four measures would do more to move the world toward an international refugee protection regime that is more aligned to the "root causes" of contemporary mass refugee flows and seeking to end non-international protracted armed conflicts. The means outlined above to implement these reforms will require concerted effort and time to realize but they are neither impractical nor unfeasible. The universalization of the definition of who is a refugee on the basis of the 1984 Cartegana Declaration would entail an UN General Assembly Resolution that would adopt a non-binding declaration that states would be free to adopt over time. The adoption of the Cartegana Declaration decennial consultative process for setting out key objectives and a comprehensive Plan of Action could be led by the UNHCR, again, with the full support of the UN General Assembly. The incorporation of mass forced displacement as an atrocity crime within the R2P doctrine would require a similar process to that which led to the adoption of the R2P doctrine itself, with all Members States coming together to ratify and to endorse the new doctrine. However, since it would be building on the pre-existing notion of "ethnic cleansing", it would be reasonable to expect that it would not be too much a "leap to make" in adding "mass forced displacement," given its proclivity in modern warfare, as an "atrocity crime," in its own right as well. The criminalization of "mass forced displacement" as a crime under International Criminal Law (ICL) would require an amendment of the 1998 Rome Statute. This presumably would also be well within the realm of possibility, given the experience of the criminalization of aggression. 
The crime of aggression, inevitably, results in mass forced displacement. The two are inherently interconnected as history has amply demonstrated, and the two should be treated the same, as very serious international crimes.

If we intend to seriously address the current "refugee crisis", then we must tackle directly war and armed conflict that is the breeding ground for the most serious international crimes such as genocide, crimes against humanity, and war crimes, "ethnic cleansing" and, as argued here, mass forced displacement. ${ }^{13}$ It must be accepted that mass forced displacement is also a direct consequence of wars and armed conflicts and that it has a direct impact on other States not only within the region where the extreme violence takes place but in all other parts of the world. It has a direct bearing on international peace and security and it has political, social, and economic implications for all host States. The use of legal and policy planning tools to reform the international refugee protection system so that it can directly respond to this reality is a necessary, but, albeit a small step, to addressing the "root causes" that produce that vast majority of the world's refugees.

Conflicts of Interest: The author declares no conflict of interest.

\section{References}

Acquaviva, Guido. 2011. Forced Displacement and International Crimes. Legal and Protection Policy Research Series; Geneva: UNHCR, June. Available online: http:/ / www.unhcr.org/4e0344b344.pdf (accessed on 18 November 2017).

Albert, Eleanor. 2017. The Rohingya Migrant Crisis. New York: Council on Foreign Relations, January 12. Available online: https: / www.cfr.org/backgrounder/rohingya-migrant-crisis (accessed on 23 August 2017).

Al-Jablawi, Hosam. 2016. Increasing Tactics of Forced Displacement in Syria. Washington: Atlantic Council, October 6. Available online: http://www.atlanticcouncil.org/blogs/syriasource/increasing-tactics-offorced-displacement-in-syria (accessed on 23 November 2017).

Andreu-Guzman, Frederico. 2012. Criminal Justice and Forced Displacement in Columbia. Case Studies on Transitional Justice and Displacement, Brookings-LSE Project on Internal Displacement, July. Available online: http:/ / www.ictj.org/sites/default/ files / ICTJ-Brookings-Displacement-Criminal-Justice-ColombiaCaseStudy-2012-English.pdf (accessed on 23 November 2017).

Andreu-Guzman, Frederico. 2013. Research Brief. In Criminal Justice and Forced Displacement: International and National Perspectives. International Centre for Transitional Justice (ICTJ) and Brookings and LSE Project on Internal Displacement, June. Available online: https:/ /www.ictj.org/sites/default/files/ICTJ-ResearchBrief-Displacement-Criminal-Justice-Andreu-Guzman.pdf (accessed on 18 November 2017).

Baire, Kurt. 1982. The Conceptual Link between Morality and Rationality. Nous 16: 78-88. [CrossRef]

BBC News. 2015. Why are so many Rohingya migrants stranded at Sea? May 18. Available online: http: / / www.bbc.co.uk/news/world-asia-32740637 (accessed on 4 October 2017).

BBC News. 2016a. Portugal's António Guterres Set to Be UN's Secretary General. October 5. Available online: http:/ / www.bbc.co.uk/news/world-37566898 (accessed on 30 September 2017).

BBC News. 2016b. Syria: The Story of Conflict. March 11. Available online: http:/ /www.bbc.com/news/worldmiddle-east-26116868 (accessed on 30 August 30).

13 "Atrocity crimes usually take place against a background of either an international or non-international armed conflict. Armed conflicts are periods characterized by a high incidence of violence, insecurity and the permissibility of acts that would otherwise not be acceptable. In addition, the capacity of States to inflict harm is usually at its peak during periods of conflict. If armed conflict is a violent way of dealing with problems, it is clear that the risk of atrocity crimes acutely increases during these periods. However, other situations that are not typical armed conflicts can also put a State under such a level of stress that it becomes more prone to serious human rights violations and, eventually, to atrocity crimes. In fact, genocide and crimes against humanity can also occur during times of peace. This is most likely when there are serious levels of political instability, threats to the security of the country or even volatility in economic or social affairs. Although situations of instability, or even of armed conflict, will not necessarily lead to the occurrence of atrocity crimes, they highly increase the likelihood of those crimes." (United Nations 2014). 
Belgrade Centre for Human Rights, Macedonian Young Lawyers Association, and Oxfam. 2017. A Dangerous 'Game:' The Pushback of Migrants, Including Refugees, at Europe's Borders. A Joint Agency Briefing Paper, April. Available online: https://www.oxfam.org/sites/www.oxfam.org/files/file_attachments/bpdangerous-game-pushback-migrants-refugees-060417-en_0.pdf(accessed on 26 August 2017).

Bellamy, Alex J. 2016. The Responsibility to Protect and the 'Migrant Crisis'. Protection Gateway, April 2. Available online: https:/ / protectiongateway.com/2016/04/02/the-responsibility-to-protect-and-the-migrant-crisis / (accessed on 19 November 2017).

Boot, Max. 2017. Better a Stalemate Than Defeat in Afghanistan. New York: Council on Foreign Relations, February 23. Available online: https://www.cfr.org/expert-brief/better-stalemate-defeat-afghanistan (accessed on 4 October 2017).

Chimni, B. S. 2001. Reforming the International Refugee Regime: A Dialogic Model. Journal of Refugee Studies 14: 151-68. [CrossRef]

Chrisafis, Angelique, and Julian Borger. 2017. Will António Guterres be the UN's best ever Secretary General. The Guardian, January 1. Available online: https://www.theguardian.com/world/2017/jan/01/willantonio-guterres-be-the-uns-best-ever-secretary-general(accessed on 30 September 2017).

Clark, Tom. 2008. The Global Refugee Regime: Charity, Management and Human Rights, 2nd ed. Victoria: Trafford Publishing.

Clark, Tom, and James C. Simeon. 2014. UNHCR International Protection Policies 2000-2013: From Cross-road to Gaps and Responses. Refugee Survey Quarterly 33: 1-33. [CrossRef]

Crocker, Sheba. 2017. Five Ways to Make the United Nations More Effective. Foggy Bottom, January 17 Voices from the US State Department Archive, 2015-2017. Available online: https:/ / medium.com/foggy-bottom/fiveways-to-make-the-united-nations-even-more-effective-8ae5c1a8fa07 (accessed on 18 November 2017).

Declarations: The Human Rights Podcast. 2017. Is Myanmar Committing Genocide Against the Rohingya? (with Dr. Thomas MacManus). Available online: https://soundcloud.com/declarationspod/rohingyagenocide (accessed on 26 August 2017).

Disasterium, Natural and Man Made Disasters. 2011-2015. Available online: http:/ /www.disasterium.com/ (accessed on 23 August 2017).

Domino, Brian, and Daniel W. Conway. 2001. Optimism and Pessimism form a Historical Perspective. In Optimism \& Pessimism: Implications for Theory, Research and Practice. Edited by Edward C. Chang. Washington: American Psychological Association. Available online: https://s3.amazonaws.com/academia. edu.documents /34814974/Optimisrm.pdf?AWSAccessKeyId=AKIAIWOWYYGZ2Y53UL3A\&Expires= 1503593763\&Signature=b6W9tJXpxJ6P7fzHLI\%2B7N95fnRY\%3D\&response-content - disposition= inline\%3B\%20filename\%3Dha_A_ia_t_P_E_S_S_I_M_I_S_M_Implications.pdf\#page=5 (accessed on 24 August 2017).

Egoism. 2014. Stanford Encyclopedia of Philosophy. December 24. Available online: https://plato.stanford.edu/ entries/egoism/ (accessed on 28 August 2017).

Fisher, Max, and Amanda Taub. 2017. Why Afghanistan's War Defies Solutions. The New York Times, August 24. Available online: https://www.nytimes.com/2017/08/24/world/asia/afghanistan-intervention-statecollapse.html?action=click\&contentCollection=Asia $\% 20$ Pacific\&module=RelatedCoverage\&region= Marginalia\&pgtype=article(accessed on 30 August 2017).

Forced Migration Online (FMO). n.d. What is forced migration? Available online: http:/ /www.forcedmigration. org/about/whatisfm (accessed on 23 August 2017).

Frenzen, Niels. 2016. NATO Expands Aegean Sea Migrant Patrols into Turkish and Greek Territorial Waters-Rescued Migrants to be Automatically Returned to Turkey. March 6. Available online: https: / / migrantsatsea.org/tag/push-back-practice/ (accessed on 26 August 2017).

Gillard, Emanuela-Chiara. 2005. Humanitarian Law, Human Rights Law and Refugee Law-The Three Pillars. Paper present at the International Association of Refugee Law Judges (IARLJ), World Conference, Stockholm, Sweden, April 21-23. Available online: https://www.icrc.org/eng/resources/documents/statement/ 6t7g86.htm (accessed on 18 September 2017).

Global Policy Forum (GPF). n.d. Universal Jurisdiction. Available online: https://www.globalpolicy.org/ international-justice/universal-jurisdiction-6-31.html (accessed on 28 September 2017). 
Greenhill, Kelly M. 2010a. Weapons of Mass Migration: Forced Displacement as an Instrument of Coercion. Strategic Insights 9: 116-59. Available online: https:/ / calhoun.nps.edu/bitstream/handle/10945/11515/SI_ V9_I1_2010_Greenhill_116.pdf (accessed on 22 November 2017).

Greenhill, Kelly M. 2010b. Weapons of Mass Migration: Forced Displacement, Coercion, and Foreign Policy. Ithaca: Cornell University Press.

Guehenno, Jean-Marie. 2017. 10 Conflicts to Watch in 2017. Foreign Policy, January 5. Available online: http: / / foreignpolicy.com/2017/01/05/10-conflicts-to-watch-in-2017/(accessed on 2 September 2017).

Hilal, Leila. 2015. The United Nations and a peace strategy process for Syria. Open Democracy: Free Thinking for the World, June 26. Available online: https:/ / www.opendemocracy.net/north-africa-west-asia/leila-hilal/ united-nations-and-peace-process-strategy-for-syria (accessed on 17 November 2017).

Hilrich, O. 2014. Human Nature, Part 1, Human Basics: Philosophy of Most Basic Knowledge. Available online: http:/ / www.humanbasics.org/index.html (accessed on 28 August 2017).

House of Lords, European Union Committee. 2016. Children in Crisis: Unaccompanied Minor Children in the EU. 2nd Report of Session 2016-2017, HL Paper 34, July 26. Available online: https:/ / publications.parliament.uk/ pa/ld201617/ldselect/ldeucom/34/34.pdf (accessed on 4 October 2017).

Human Rights Watch. 2015. Europe's Refugee Crisis: An Agenda for Action. November 16. Available online: https: / /www.hrw.org/report/2015/11/16/europes-refugee-crisis/agenda-action (accessed on 26 August 2017).

International Committee of the Red Cross (ICRC). 1998. Treaties, State Parties and Commentaries, Rome Statute of the International Criminal Court. July 17. Available online: https://ihl-databases.icrc.org/ihl/INTRO/585? OpenDocument (accessed on 17 September 2017).

International Committee of the Red Cross (ICRC). 2002. The Law of Armed Conflict, Belligerent Occupation. June. Available online: https://www.icrc.org/eng/assets/files/other/law9_final.pdf (accessed on 20 September 2017).

International Committee of the Red Cross (ICRC) Customary IHL. n.d. The Act of Displacement. chp. 38, Rule 129. Available online: https://ihl-databases.icrc.org/customary-ihl/eng/docs/v1_cha_chapter38_rule129\#Fn_ 11_31 (accessed on 3 October 2017).

Immigration and Refugee Board of Canada. 1996. Chairperson's Guideline 1: Civilian Non-Combatants Fearing Persecution in Civil War Situations. Guidelines Issued by the Chairperson pursuant to Section 65(3) of the Immigration Act. Available online: http://www.irb-cisr.gc.ca/Eng/BoaCom/references/pol/GuiDir/ Pages/GuideDir01.aspx (accessed on 16 September 2017).

International Criminal Court. n.d.a. Trying Individuals for Genocide, War Crimes and Crimes against Humanity. Available online: https:/ / www.icc-cpi.int/ (accessed on 3 October 2017).

International Criminal Court. n.d.b. Crime of Aggression-Amendments Ratification. Available online: https:/ / asp.icc-cpi.int/en_menus/asp/crime\%20of\%20aggression/pages/default.aspx (accessed on 19 November 2017).

International Justice Resource Center. n.d. Universal Jurisdiction. Available online: http:/ /www.ijrcenter.org/ cases-before-national-courts/domestic-exercise-of-universal-jurisdiction/ (accessed on 28 September 2017).

Islam, Mohammad Rabiul. 2016. The International Criminal Court: Its Success and Limitations for Pursuing International Justice. Journal of Civil $\mathcal{E}$ Legal Sciences 5: 1-6. Available online: file:/ / C:/Users/esouser/Downloads/the-international-criminal-court-its-success-and-limitationsfor-pursuinginternational-justice-2169-0170-1000180.pdf (accessed on 19 November 2017).

Joseph, Paul, ed. 2017. The SAGE Encyclopedia of War: Social Science Perspectives. Thousand Oaks: Sage Publications Inc. Available online: https://books.google.co.uk/books?id=idw0DQAAQBAJ\&pg= PA306\&lpg=PA306\&dq =are+people+who+flee+a+war+zone+covered + by + the + Geneva + Conventions? \&source=bl\&ots=Ko8UBCWWqJ\&sig=19BsAX4eUgemt6eis5pVvxvV19M\&hl=en\&sa=X\&ved= 0ahUKEwjZxMCRyNbWAhWLfFAKHcwfAUgQ6AEISjAF\#v=onepage\&q=are\%20people\%20who\%

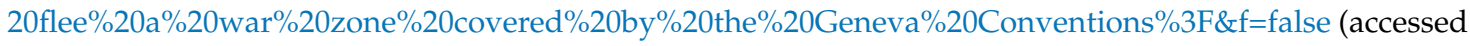
on 4 October 2017).

Lichtenheld, Adam. 2014. Forced Migration as a Weapon of War in Iraq and Beyond. UN DISPATCH, July 1. Available online: https:/ / www.undispatch.com/forced-migration/(accessed on 22 November 2017). 
Marc, Alexandre. n.d. Conflict and Violence in the $21^{\text {st }}$ Century: Current Trends as Observed in Empirical Research and Statistics. World Bank Group, Fragility, Conflict and Violence. Available online: http:/ /www.un.org/pga/70/wp-content/uploads/sites/10/2016/01/Conflict-and-violence-in-the-21stcentury-Current-trends-as-observed-in-empirical-research-and-statistics-Mr-Alexandre-Marc-ChiefSpecialist-Fragility-Conflict-and-Violence-World-Bank-Group.pdf (accessed on 28 August 2017).

McAdam, Jane. 2012. Climate Change, Forced Migration, and International Law. Oxford: Oxford University Press.

Migration Policy Institute (MPI). n.d. Moving Europe beyond Crisis; Europe's Migration Crisis: A Status Report and the Way Forward. Available online: http:/ / www.migrationpolicy.org/programs/moving-europe-beyondcrisis?gclid=Cj0KCQjwz_TMBRD0ARIsADfk7hRoK0dpEGP-Q0tSDqMcZxsjOmqFUHgxwRqwMPIM6RWIZT3lgN2gvgaApSbEALw_wcB (accessed on 23 August 2017).

Organization for African Unity Convention. 1969. Governing Specific Aspects of the Refugee Problem in Africa, UN Treaty Series, No. 14691. Adopted Addis Abba 10 September 1969, entered into force 20 June 1974. Available online: http://www.unhcr.org/uk/about-us/background/45dc1a682/oau-conventiongoverning-specific-aspects-refugee-problems-africa-adopted.html (accessed on 3 October 2017).

Oxfam. 2017. South Sudan Crisis Appeal. Available online: http://www.oxfam.org.uk/home/what-we-do/ emergency-response/south-sudan-crisis?pscid=ps_ggl_Emergency+-+South+Sudan\&gclid=CjwKCA (accessed on 2 September 2017).

Pfanner, Toni. 2009. Editorial: Typology of Armed Conflict. International Review of the Red Cross. No. 873. March 31. Available online: https://www.icrc.org/en/international-review/article/editorial-typology-armedconflicts (accessed on 28 August 2017).

Piguet, Etienne. 2008. Climate Change and Forced Migration. New Issues in Refugee Research, Research Paper No. 153, UNHCR, Policy Development and Evaluation Service. January. Available online: http:/ / www. unhcr.org/research/working/47a316182/climate-change-forced-migration-etienne-piguet.html (accessed on 20 August 2017).

Prohibition, United States History. 1920-1933. Encyclopedia Britannica. Available online: https://www.britannica. com/event/Prohibition-United-States-history-1920-1933 (accessed on 4 October 2017).

Refugeehood. n.d. CARFMS-ORTT. Available online: http://rfmsot.apps01.yorku.ca/glossary-of-terms / refugeehood/ (accessed on 20 August 2017).

Rettner, Rachael. 2017. Here are the Top Causes of Death Worldwide. LiveScience, September 15. Available online: https: / / www.livescience.com/60429-global-disease-death-burden.html(accessed on 17 September 2017).

Rome Statute of the International Criminal Court. 1998. Available online: http://legal.un.org/icc/statute/ romefra.htm (accessed on 17 September 2017).

Spencer, Richard. 2015. UN at 70: Five Greatest Successes and Failures. The Telegraph, September 15. Available online: http:/ / www.telegraph.co.uk/news/worldnews/europe/switzerland/11700969/UN-at-70-Fivegreatest-successes-and-failures.html(accessed on 17 November 2017).

Storey, Hugo. 2012. Armed Conflict in Asylum Law: The 'War Flaw'. Refugee Survey Quarterly 31: 1-32. [CrossRef]

The Lancet. 2017. Global Burden of Disease. Available online: http:/ /www.thelancet.com/gbd (accessed on 17 September 2017).

UN News Centre. 2016a. UN Envoy Urges all Afghans, Including the Taliban, to Enter the Peace Process and Reject Endless War. December 19. Available online: http://www.un.org/apps/news/story.asp?NewsID= 55834\#.WdIY01tSzIU (accessed on 1 October 2017).

UN News Centre. 2016b. António Guterres Appointed Next UN Secretary-General by Acclamation. October 13. Available online: http:/ / www.un.org/apps/news/story.asp?NewsID=55285\#.Wc_g51tSzIU (accessed on 30 September 2017).

UN News Centre. 2017. 'Moment of Crisis' in Syria Calls for Serious Search for Political Solution-UN Envoy. April 12. Available online: http://www.un.org/apps/news/story.asp?NewsID=56552\#.WdDs_1tSzIU (accessed on 1 October 2017).

UN Department of Political Affairs, United Nations Assistance Mission in Afghanistan (UNAMA). n.d. Available online: https: / / unama.unmissions.org/mission-statement (accessed on 1 October 2017). 
UNHCR. 1969. OAU Convention: Governing the Specific Aspects of Refugee Problems in Africa. Adopted by the Assembly of Heads of States and Government at its Sixth Ordinary Session, Addis Abba, 10 September 1969, Entry into Force 20 June 1974. Available online: http:/ / www.unhcr.org/uk/about-us/background/ 45dc1a682/oau-convention-governing-specific-aspects-refugee-problems-africa-adopted.html (accessed on 10 December 2017).

UNHCR. 1984. Cartagena Declaration on Refugees. Paper present at the Colloquium on the International Protection of Refugees in Central America, Mexico and Panama, Cartagena De Indias, Colombia, November 22. Available online: http:/ / www.unhcr.org/45dc19084.html (accessed on 22 September 2017).

UNHCR. 2003. Agenda for Protection, 3rd ed. October. Available online: http:/ /www.unhcr.org/uk/protection/ globalconsult/3e637b194/agenda-protection-third-edition.html (accessed on 23 September 2017).

UNHCR. 2011. Handbook on Procedures and Criteria for Determining Refugee Status, under the 1951 Convention and the 1967 Protocol Related to the Status of Refugees. December. Available online: http:/ / www.unhcr.org/publications/legal/3d58e13b4/handbook-procedures-criteria-determiningrefugee-status-under-1951-convention.html (accessed on 8 September 2017).

UNHCR. 2014. The Brazil Declaration. Available online: http://www.unhcr.org/uk/brazil-declaration.html (accessed on 22 September 2017).

UNHCR. 2016. Global Trends: Forced Displacement 2015. Geneva: United Nations High Commissioner for Refugees. Available online: http:/ / www.unhcr.org/576408cd7.pdf (accessed on 4 October 2017).

UNHCR. 2017a. Note on International Protection. Paper present at the 69th Meeting Standing Committee of the Executive Committee of the High Commissioners Programme, Geneva, Switzerland, June 16. Available online: http:/ / www.unhcr.org/uk/excom/standcom/594a56cf7/note-on-international-protection.html (accessed on 23 September 2017).

UNHCR. 2017b. Global Trends: Forced Displacement 2016. Geneva: United Nations High Commissioner for Refugees. Available online: http://www.unhcr.org/statistics/unhcrstats/5943e8a34/global-trends-forceddisplacement-2016.html (accessed on 29 August 2017).

UNHCR, Conferences and Meetings. n.d. Available online: http://www.unhcr.org/uk/conferences-andmeetings.html (accessed on 23 September 2017).

UNICEF. 2017. Number of unaccompanied children soars. Al Jazeera, May 18. Available online: http: / / www.aljazeera.com/news/2017/05/unicef-number-unaccompanied-refugee-children-soars170518063920980.html(accessed on 2 September 2017).

UNICEF Press Release. 2017. Five-fold increase in the number of migrant and refugee children travelling alone since 2010-UNICEF. May 17. Available online: https:/ / www.unicef.org/media/media_95997.html (accessed on 2 September 2017).

United Nations. 2009. Implementing the Responsibility to Protect. Report of the Secretary-General, A/63/677, January 12. Available online: http://www.un.org/en/ga/search/view_doc.asp?symbol=A/63/677 (accessed on 1 October 2017).

United Nations. 2014. Framework of Analysis for Atrocity Crimes: A Tool for Prevention. New York: United Nations. Available online: http:/ / www.un.org/en/genocideprevention/documents / publications-and-resources / Framework\%20of\%20Analysis\%20for\%20Atrocity\%20Crimes_EN.pdf (accessed on 4 October 2017).

United Nations. 2015. United Nations Shares Responsibility for Peace With Regional Organizations, Says Secretary-General, Opening All-Day Security Council Debate. Meetings Coverage and Press Releases. New York: Security Council. SC/12011. August 18.Available online: https://www.un.org/press/en/2015/sc12011.doc. htm (accessed on 2 October 2017).

United Nations. 2016. Report of the United Nations High Commissioner for Refugees, Covering the Period from 1 July 2015-30 June 2016. New York: United Nations.

United Nations. 2017a. Supplement No. 1. In Report of the Secretary-General on the Work of the Organization. New York: United Nations. A/72/1. July 28. Available online: http://undocs.org/A/72/1 (accessed on 3 October 2017).

United Nations. 2017b. Secretary-General Says 'No One is Winning Today's Wars, Everyone is Losing,' as Security Council Debates Protection of Civilians in Armed Combat. Meetings Coverage and Press Releases. May 25. New York: United Nations. Available online: https:/ /www.un.org/press/en/2017/sgsm18537.doc.htm (accessed on 13 December 2017). 
United Nations Department of Political Affairs. n.d. Prevention and Mediation. Available online: http://www.un. org/undpa/en/diplomacy-mediation (accessed on 22 November 2017).

United Nations. n.d. Charter of the United Nations, Preamble. Available online: http://www.un.org/en/sections / un-charter/preamble/index.html (accessed on 3 October 2017).

United Nations Office of Genocide Prevention and Responsibility to Protect. n.d. Definitions, Ethnic Cleansing. Available online: http://www.un.org/en/genocideprevention/ethnic-cleansing.html (accessed on 4 October 2017).

United Nations Peacekeeping. n.d. What is Peacekeeping? Available online: http://www.un.org/en/ peacekeeping/operations / peacekeeping.shtml (accessed on 29 September 2017).

United Nations Peacemaker. n.d. Available online: https:/ / peacemaker.un.org/ (accessed on 22 November 2017).

United Nations, Department of Peacekeeping Operations, Department of Field Support. 2008. United Nations Peacekeeping Operations: Principles and Guidelines. New York: United Nations. Available online: http: / / www.un.org/en/peacekeeping/documents/capstone_eng.pdf (accessed on 1 October 2017).

United Nations, Department of Political Affairs, UNAMA, Mandate. n.d. United Nations Assistance Mission in Afghanistan. Available online: https:/ / unama.unmissions.org/mandate (accessed on 10 December 2017).

Uppsala University, Department of Peace and Conflict Research. 2015. Uppsala Conflict Data Program (UCDP) 2015. Available online: http:/ / www.pcr.uu.se/ (accessed on 22 August 2017).

Von Einsiedel, Sebastian, Louise Bosetti, James Cockayne, Cale Salih, and Wilfred Wan. 2017. Civil War Trends and the Changing Nature of Armed Conflict. Occasional Paper 10. New York: United Nations Centre for Policy Research, March. Available online: https://i.unu.edu/media/cpr.unu.edu/attachment/2534/OC_10CivilWarTrendsandChangingNatureofArmedConflict-05-2017.pdf (accessed on 30 September 2017).

Woolf, Christopher. 2016. How do wars end? Not usually with unconditional surrender. PRI's The World, December 17. Available online: https:/ / www.pri.org/stories/2016-12-07/how-do-wars-end-not-usuallyunconditional-surrender(accessed on 23 November 2017).

Zolberg, Aristide R., Astri Suhrke, and Sergio Aguayo. 1989. Escape from Violence: Conflict and the Refugee Crisis in the Developing World. Oxford: Oxford University Press.

(C) 2017 by the author. Licensee MDPI, Basel, Switzerland. This article is an open access article distributed under the terms and conditions of the Creative Commons Attribution (CC BY) license (http:/ / creativecommons.org/licenses/by/4.0/). 